\title{
Ympäristöindeksi kertoo viljelyn ympäristötehokkuuden
}

\author{
Jaakko Laurinen \\ Raisio Oyj, PL 101, 21201 Raisio, jaakko.laurinen@raisio.com
}

Elintarvikkeiden hiilidioksidipäästöistä merkittävä osa syntyy jo niiden raaka-aineiden tuotannossa maataloudessa. MTT:n elinkaarianalyysin perusteella esimerkiksi Raisio Oyj:n valmistamien Elovena -kaurahiutaleiden tuotannon hiilidioksidipäästöistä jopa yli 60 \% syntyy kauran viljelyssä. On selvää, että ruoan tuotannon ilmastovaikutuskeskustelussa syntyy painetta nimenomaan maataloutta kohtaan. Tästä syystä tarvitaan myös menetelmiä viljelyn ympäristövaikutusten mittaamiseen ja parantamiskohteiden hakemiseen. Viljanviljelyn ympäristövaikutusten vertailuun Raisio on kehittänyt ympäristöindeksin, jolle on haettu patenttia. Esityksessä kerrotaan indeksin periaatteita, tuloksia ja tulkintoja. Kyseessä on käytännön sovellutus, jolla viljelijä voi mitata oman toimintansa ympäristötehokkuutta ja arvioida keinoja ympäristötehokkuuden parantamiseen.

Aineistona ovat esinäytekyselystä saatavat viljelytiedot sekä viljan esinäytteestä laboratoriossa määritetty laatu. Aineisto kuvaa nimenomaan Raision tuotantolaitoksissa käytettävää viljaa. Tiedot saadaan vuosittain yli 2000:sta esinäytteestä. Indeksin avulla eri tavoin tuotetun viljan tuotannon ympäristötehokkuuden vertailu on helppoa ja yhteismitallista. Käytännöllistä ja helppokäyttöistä menetelmää tullaan viljelyneuvonnan lisäksi hyödyntämään myös kuluttajainformaatiossa ja tuotekehityksessä.

Menetelmässä lasketaan indeksi sadon tuottamiseen kulutetun energian suhteesta jyväsadossa olevan energiaan. Samasta aineistosta voidaan laskea myös indeksi sadon tuottamisesta syntyvien hiilidioksidipäästöjen ja jyväsadon sitoman hiilidioksidin suhde. Aineistosta voidaan laskea myös perinteinen ravinnetase.

Sadon sitoman hiilidioksidin ja sadon tuottaman energian laskemiseen käytetään seuraavia parametreja: sato kg/ha, valkuaispitoisuus, tärkkelyspitoisuus, öljy- ja rasvapitoisuus sekä tuhka. Sadon tuottamisessa syntyvien hiilidioksidipäästöjen ja käytetyn energian laskemiseen käytetään seuraavia parametreja: lannoitus, kalkitus, kasvinsuojelu, konetyö viljelyssä sekä sadon käsittely.

Tuloksena saadaan tunnusluku, joka kuvaa viljelijän onnistumista omassa viljelyssään ympäristön kannalta. Viljelijälle tärkeintä tietoa on energian käytön mittaaminen suhteessa satoon. Varsinkin energiahintojen noustua on hyvä verrata omaa energiatehokkuuttaan suhteessa muihin. Viljelijä voi verrata omaa indeksilukuaan parhaaseen ja huonoimpaan neljännekseen, sillä tulokset ovat nähtävillä sopimusviljelijöille tarkoitetuilla extranet -sivuilla. Kuluttaja on puolestaan kiinnostuneempi viljelyn aiheuttamista hiilidioksidipäästöistä saatuun tulokseen nähden.

Johdonmukaisesti mittaustapa näyttää esimerkiksi sen, että satotason kasvaessa viljely tulee useimmiten ympäristöystävällisemmäksi. Hyvä sato on parasta ympäristönsuojelua.

Asiasanat: Ympäristö, ympäristöindeksi, energiatehokkuus 


\section{Johdanto}

Raisio Oyj on elintarvikkeita ja niiden terveysvaikutteisia ainesosia sekä rehuja ja maltaita valmistava yritys, jonka tärkein raaka-aine on vilja. Viljaa käytetään Raision tuotantolaitoksissa noin 550 milj kg vuodessa. Viljanhankinnan perusta on sopimusviljely, joka mahdollistaa suoran vuorovaikutuksen viljelijöiden kanssa ja raaka-ainetuotannon kehittämisen.

Raision strategian olennaisena osana on toiminnan ekologisuus. Pyrkimys ympäristöystävällisyyteen näkyy kaikessa Raision toiminnassa ja tästä osoituksena ovat esimerkiksi kasvava kirjo Raision tuotteita, joista löytyy hiilidioksidiekvivalenttia kuvaava luku. Elintarvikkeiden hiilijalanjälkilaskennat osoittavat useimmiten merkittävän osuuden jalanjäljestä syntyvän heti raakaaineen tuotannossa eli maataloudessa. Näin on useiden Raisio Oyj:n valmistamien tuotteidenkin osalta, joista hiilidioksidiekvivalentti on tiedossa. Esimerkiksi Raision valmistamien Elovena kaurahiutaleiden tuotannon hiilidioksidipäästöistä jopa yli 60 \% syntyy kauran viljelyssä. On selvää, että ruoan tuotannon ilmastovaikutuskeskustelussa syntyy painetta nimenomaan maataloutta kohtaan. Siksi myös tällä saralla on pystyttävä kehittymään. Ensimmäinen askel tähän on nykyisen tason mittaaminen.

Viljelyn ympäristötehokkuuden mittaamiseen Raisio on luonut oman ympäristöindeksin. Siinä kaikki viljelyyn käytettävät tuotantopanokset muutetaan energiaksi ja tätä määrää verrataan jyväsadon mukana pellolta poistuvaan energiaan. Tuloksena oleva indeksiluku kertoo energiatehokkuuden yhden luvun avulla. Mitä korkeampi luku on, sitä parempi energiatehokkuus on ollut. Saman aineiston perusteella voidaan laskea myös hiilidioksidipäästöjen ja jyväsadon sitoman hiilidioksidin suhde, jota voidaan kutsua hiilidioksidi-indeksiksi. Nämä luvut eivät yksinään kerro vielä mitään, mutta kun niitä verrataan muiden viljelijöiden lukuihin tai omaan tulokseen aiemmilta vuosilta, saadaan jo arvokasta tietoa oman tuotannon ympäristöystävällisyydestä. Tavoitteena on siis toisaalta tuottaa tietoa elintarviketeollisuuden raaka-aineiden tuotannon ympäristövaikutuksista ja toisaalta tarjota viljelijöille yksinkertainen työväline oman toimintansa arviointiin ympäristön kannalta. Indeksin tuloksia ja sitä varten kerättävää aineistoa voidaan hyödyntää viljelyneuvonnassa, kuluttajainformaatiossa ja tuotekehityksessä.

\section{Aineisto ja menetelmät}

Raisio kerää viljasadosta esinäytteitä kartoittaakseen sadon laatua ja ohjatakseen eri laatuja sopiviin käyttötarkoituksiin. Esinäyteanalyysi on myös viljelijälle tärkeä tieto, jota tarvitaan sadon markkinoinnissa ja arvon määrityksessä. Esinäytteiden keruun yhteydessä on perinteisesti kerätty taustatietoa esinäytettä vastaavan sadon viljelystä ja satotasosta. Esinäytekyselyssä kerätään seuraavat viljelyä koskevat tiedot: maalaji, maan $\mathrm{pH}$, lannoitus (pääravinteiden eli typen, fosforin ja kaliumin määrät hehtaarille), sato (kg/ha), kasvinsuojelutoimenpiteet päätyypeittäin (peittaus, rikkakasvitorjunta, kasvunsäädekäsittely, kasvitautitorjunta, tuhoeläintorjunta ja ruiskutuskertojen lukumäärä), muokkaustapa (kyntö, kevytmuokkaus tai suorakylvö suoraan sänkeen). Näiden lisäksi huomioidaan kalkitus, konetyö ja sadon käsittely, mutta näiden osalta luvut on vakioitu. Tosin konetyöstä kasvinsuojeluruiskutusten todellinen määrä selviää esinäytekyselystä ja satotason mukaan tehdään korjaus puintikustannuksiin. Vakioarvojen käyttö osassa aineistoa tehdään, koska ympäristöindeksin aineiston keruu on haluttu pitää riittävänä yksinkertaisena viljelijälle, jotta hyväksyttyjä vastauksia saadaan merkittävä määrä ja tuloksista saadaan käytännön työkalu, joka saa mahdollisimman monet viljelijät ajattelemaan tuotantonsa ympäristövaikutuksia. Tällä hetkellä viljelijä saa siis omaa viljelyään koskevan indeksitiedon pelkästään sillä, että täyttää esinäytekyselyn huolellisesti. Raisiolle olennaista on se, että saadaan kerättyä nimenomaan sen tuotantolaitoksissa käytetyn raaka-aineen tietoja eikä olla esimerkiksi maakohtaisten keskiarvojen varassa minkään tärkeän muuttujan osalta.

Toinen puoli aineistoa syntyy esinäytteestä tehtävästä laboratorioanalyysistä. Laboratorioanalyysissä mitataan sadon proteiinipitoisuus. Tämän perusteella voidaan arvioida sadon tärkkelyspitoisuus, rasvapitoisuus ja tuhkan määrä. Vuonna 2008 indeksilaskentaan hyväksyttyjen havaintojen määrä oli 2119 kpl, joista ohranäytteitä oli 1175 kpl, kevätvehnänäytteitä 595 kpl, 
syysvehnänäytteitä $186 \mathrm{kpl}$, kauranäytteitä 88 kappaletta ja ruisnäytteitä 75 kpl. Maantieteellisesti havainnoista suurin osa on Varsinais-Suomesta, Satakunnasta, Pirkanmaalta ja Uudeltamaalta.

Laskennassa aineiston arvot muunnetaan energiaksi eli jouleiksi jos halutaan laskea energiaindeksi. Vastaavasti arvoista voidaan määritellä niihin sitoutuneen hiilidioksidin määrä, jos halutaan laskea hiilidioksidi-indeksi. Energiaindeksissä jyväsatoon sitoutuneen energian määrä jaetaan sadon tuottamiseen käytetyn energian määrällä. Syntynyt luku on energiaindeksi. Mitä korkeampi indeksin arvo on, sen parempi tulos on ympäristön kannalta, koska tällöin tuotantopanokset on kotiutettu tehokkaasti sadon mukana.

Ravinnetasetta käytetään ympäristöindeksin vierellä lisätietona. Ravinnetase on paljon käytetty ja hyvin kuvaava väline ravinteiden käytön tehokkuuden mittaamiseen. Ravinnetase lasketaan myös Raision keräämästä aineistosta typen ja fosforin osalta. Ravinnetase on lannoituksessa annetun typen ja fosforin määrä vähennettynä sadon mukana poistuvan typen ja fosforin määrällä. Mitä matalampi ravinnetaseen arvo on, sitä paremmin ravinteet on käytetty. Negatiivinen ravinnetase kertoo, että lannoituksen lisäksi myös maan omia ravinnevarastoja on käytetty sadon tuottamiseen.

\section{Tulokset ja tulosten tarkastelu}

Energiaindeksin arvojen vaihteluväli vuoden 2008 tuloksissa on 3,1 - 11,4. Indeksin taso vaihtelee kasvien välillä suuresti. Kasveista parhaiten menestyy kaura, sillä sen indeksiarvojen minimi on huomattavasti korkeampi kuin muilla kasveilla. Kauralla on helpompi päästä hyvään energiatehokkuuteen. Tämä kertoo, että kaura, joka on esimerkiksi Elovena -tuotteissa tärkeä raakaaine, on kasvina varsin ympäristöystävällinen verrattuna muihin viljoihin. Tämä lienee seurausta siitä, että kaura on vaatimaton ja taudinkestävä kasvi, joka palkitsee myös hyvällä sadolla, kunhan viljelyn perusasiat ovat kunnossa.

\begin{tabular}{cc}
\hline Kaura & Energiaindeksi \\
\hline Huonoin neljännes & $6,4-7,7$ \\
Toinen neljännes & $7,6-8,3$ \\
Kolmas neljännes & $8,3-8,8$ \\
Paras neljännes & $8,8-11,4$ \\
\hline
\end{tabular}

Taulukko 1. Kauran energiaindeksi neljänneksittäin vuonna 2008.

Ohran indeksien arvot lähtevät huomattavasti alempaa kuin kauran, mutta parhaimmisto on kuitenkin yltänyt lähes yhtä hyvään lukemaan. Parhaimman neljänneksen kohdalla satotaso on selvästi korkeampi ja ravinnetase on erittäin hyvä.

\begin{tabular}{lcccc}
\hline \multicolumn{1}{c}{ Ohra } & Energiaindeksi & $\begin{array}{c}\text { Satotaso kg/ha } \\
\text { k.a }\end{array}$ & $\begin{array}{c}\text { Typpitase } \\
\text { kg N k.a }\end{array}$ & $\begin{array}{c}\text { Fosforitase kg } \\
\text { P k.a }\end{array}$ \\
\hline Huonoin neljännes & $3,1-6,3$ & 3576 & 33 & -3 \\
Toinen neljännes & $6,3-6,8$ & 4238 & 23 & -6 \\
Kolmas neljännes & $6,8-7,3$ & 4652 & 17 & -8 \\
Paras neljännes & $7,3-11,2$ & 5168 & 4 & -12 \\
\hline Kaikkien näytteiden keskiarvo & 4409 & 19 & -7 \\
\hline
\end{tabular}

Taulukko 2. Ohran energiaindeksi neljänneksittäin vuonna 2008 verrattuna satotasoon ja ravinnetaseisiin.

Kevätvehnän tehokas tuotanto vaatii enemmän tuotantopanoksia erityisesti lannoituspuolella, kuin ohra ja kaura, joten sen kohdalla paras arvo jää ohran ja kauran lukemista. Ravinnetase kertoo kuitenkin, että lannoitus on tullut kohtuullisesti käyttöön varsinkin kahdella parhaalla neljänneksellä. 


\begin{tabular}{ccccc}
\hline Kevätvehnä & Energia-indeksi & $\begin{array}{c}\text { Satotaso kg/ha } \\
\text { k.a }\end{array}$ & $\begin{array}{c}\text { Typpitase } \\
\text { kg N k.a }\end{array}$ & $\begin{array}{c}\text { Fosforitase kg } \\
\text { P k.a }\end{array}$ \\
\hline Huonoin neljännes & $3,3-5,6$ & 3258 & 51 & -4 \\
Toinen neljännes & $5,6-6,2$ & 4004 & 39 & -7 \\
Kolmas neljännes & $6,2-6,8$ & 4377 & 29 & -8 \\
Paras neljännes & $6,8-10,0$ & 5011 & 11 & -13 \\
\hline \multirow{2}{*}{ Kaikkien näytteiden keskiarvo } & 4162 & 32 & -8 \\
\hline
\end{tabular}

Taulukko 3. Kevätvehnän energiaindeksi neljänneksittäin vuonna 2008 verrattuna satotasoon ja ravinnetaseisiin.

Muokkaustapojen välinen vertailu antaa energiaindeksien parhaan keskiarvon suorakylvölle, mutta myös kevytmuokkauksen ja kynnön tulokset ovat varsin hyviä. Koska suorakylvössä tuotantoon kuluu vähemmän öljyä, on siinä helpompi saada kohtuullinen tulos ympäristön kannalta. Tämä näkyy siinä, että indeksin minimiarvo on suorakylvössä korkeampi kuin muissa kylvötavoissa. Vaikka sato ei olisi aivan paras mahdollinen, voi suorakylvöllä saada melko hyvän lukeman energiaindeksiksi. Jos suorakylvöllä saa korkean sadon, on tuloksena helposti parhaan neljänneksen lukema. Kaikilla kylvötekniikoilla on kuitenkin päästy onnistuessa hyviin tuloksiin ja kaikkia muokkaustapoja myös löytyy parhaasta neljänneksestä.

\begin{tabular}{ccc}
\hline Muokkaustapa & Kevätvehnän Energiaindeksi k.a & Ohran Energiaindeksi k.a \\
\hline Suorakylvö & 6,56 & 7,12 \\
Kevytmuokkaus & 6,29 & 6,86 \\
Kyntö & 6,06 & 6,64 \\
\hline Keskiarvo & 6,23 & 6,82 \\
\hline
\end{tabular}

Taulukko 4. Kevätvehnän ja mallasohran energiaindeksit muokkaustavoittain vuonna 2008.

\section{Johtopäätökset}

Tulosten tarkastelu osoittaa sen, että sadon noustessa indeksin arvo kasvaa. Menetelmän mukaan johtopäätöksenä olisi, että energiatehokkain viljely saadaan aikaan kun saavutetaan huippusato. Huonoon indeksiarvoon on yleensä löydettävissä viljelytiedoista selkeä syy. Satotaso on jäänyt pienemmäksi kuin käytetyistä panoksista olisi pitänyt saada aikaan. Sääolot ovat yleensä perimmäinen syy sadon romahtamiseen. Voidaan kuitenkin miettiä olisiko huono tulos ollut nähtävissä jo kasvukauden aikana ja olisiko tuotantopanosten käyttöä voinut vähentää, jolloin olisi tullut säästöä niin taloudellisesti kuin myös ympäristön kannalta. Lannoituksen jakaminen useampaan käsittelyyn ja kasvinsuojelutoimenpiteet vain todettuun tarpeeseen ovat keinoja riskin pienentämiseen. Luonnon kannalta tärkeää olisi, että hajonta vähenisi nykyisestä eli energiankäytön kannalta hyvin tehottomat tulokset saataisiin vähenemään. Toki kaikilla on parantamisen varaa ja parhaisiin tuloksiin päässeistä voidaan ottaa oppia.

Osa indeksilaskennan aineistoarvoista on vakioitu. Samalla periaatteella voitaisiin luonnollisesti laskea arvoja myös tarkemmasta tilakohtaisesta aineistosta, joka kerätään varta vasten tähän tarkoitukseen ja se voisi kattaa tietoja myös esimerkiksi eri peltotyövaiheiden ja kuivauksen todellisesta polttoainekulutuksesta sekä toteutuneista kalkitusmääristä. Tämä mahdollistaisi tarkemman analyysin, jossa eri toimintamallien erot tulevat paremmin näkyviin. Tulevina vuosina aihepiirin ympärillä tullaan varmasti toteuttamaan myös tämänkaltaisia tieteellisiä tutkimusprojekteja. 